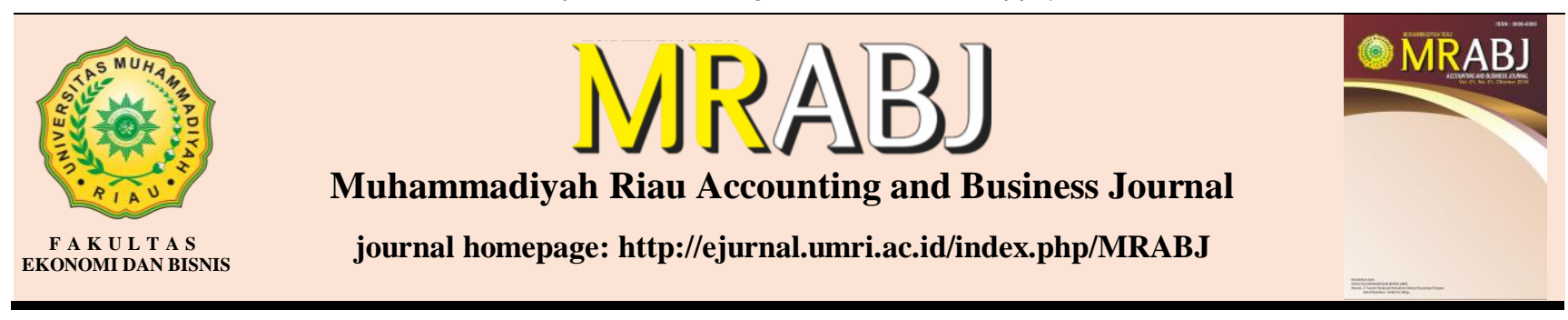

\title{
CORPORATE GOVERNANCE INDEX, CORPORATE OWNERSHIP STRUCTURE AND AUDIT COMMITTEE ON DEBT COSTS
}

\author{
Siti Nur Azizah, Yulia Nurcahyani \\ Fakulty of Economic and Business, Universitas Muhammadiyah Purwokerto, Banyumas, Indonesia \\ Email: sitinurazizah@ump.ac.id
}

\section{A R T I C L E I N F O}

Article History:

Received: 30 Maret 2020

Accepted: 30 April 2020

Available online: 31 Mei 2020

Keywords:

CGI, Managerial,

Institutional,

Audit Committee,

Debt Costs.

\section{A B S T R A C T}

This study aims to analyze corporate governance index and ownership structure and audit committee on the cost of debt. The study based on agency theory by Jensen and Meckling in 1976. This study use secondary data derived from financial statements of companies participating in the Corporate Governance Perception Index (CGPI) for 2014-2018 which are listed on the Indonesia Stock Exchange. The method of data collection in this study used purposive sampling. The data was analyzed by multiple linear regression analysis. The results of this study indicate that corporate governance index and institutional ownership negatively effect on the cost of debt. In contrast, audit committee and managerial ownership has no impact on the cost of debt. The findings in this study can be beneficial for investors in assessing the governance of a company in managing its debt. Investors can consider for an investment decision both long term and short term.

\section{Introduction}

One of companies's method to conduct funding is by debt. Debt is an approach to obtain funds from external parties to support business activities. These funds incur debt costs for companies as well as interest rates received by creditors as a rate of return (Ashkhabi and Agustina 2015).

However, not all companies can adjust the benefits of the acquisition of funds (debt) compared to the risk of costs incurred. One of the companies involved in the case of debt costs is the Lippo Group. From 2014 to 2017 the Lippo Group experienced a downward trend, for instance at Lippo Karawaci Tbk (LPKR), which has the largest debt, among others, with a value of $\mathrm{Rp} 13.8$ trillion. While the ratio of debt to earnings before interest, taxes, depreciation and amortization (EBITDA) of 7.32 times. It means that the debt burden borne by the company is 7.3 times greater than the profits. This ratio has continued to increase in the past four years, which in 2014 reached 
a low of 2.6 times. So that in 2018 threatened to go bankrupt because it bears too much debt burden. The deterioration of financial conditions and a large debt burden have caused Lippo Group companies to face short and medium term liquidity problems. The impact experienced from the Lippo Group case was the share price which declined by $60 \%$ (Tamara, 2018).

Such cases can be avoided if the company has good corporate governance (GCG). The measurement of GCG implementation by companies can use several indicators including Corporate Governance Index (CGI), managerial ownership structure, institutional ownership and audit committee (Askhabi and Agustina, 2015). The implementation of GCG in a company can be assessed from the high CGI obtained by the company. For creditors, CGI can be a reference in managing loan funds given by creditors (Yenibra, 2015). Several previous studies conducted by Ashkhabi and Agustina (2015), Sari et al (2018) and Erniawati and Mawardi (2019) stated that the CGI had a negative effect on debt costs. However, research conducted by Saputra and Faizal (2016) states that the corporate governance index has a positive effect on debt costs.

Managerial ownership is a condition when a shareholder has a role in the management of the company. In a study conducted by Wardani and Rumahorto (2018) states that managerial ownership has a positive effect on the cost of debt. In contrast, Rahmawati (2015) and Mahmoudi and Hashempour (2016) state that managerial ownership negatively affects the cost of debt. Institutional ownership has the ability to control management through effective monitoring processes, thereby reducing earnings manipulation. In a study conducted by Mahmoudi and Hashempour (2016), Meiriasari (2017) and Octafilia and Sandika (2018) stated that institutional ownership negatively affected the cost of debt. However, research conducted by Samhudi (2016) states that institutional ownership has a positive effect on debt costs.

The audit committee has the duty to oversee the performance of the company's management so that the management's performance is in accordance with the provisions of the creditor (principal). In a study conducted Sari et al (2018) stated that the audit committee negatively affects the cost of debt. However, research conducted by Sutarti and Pranaditya (2018) states that the audit committee has a positive effect on debt costs.

Based on the economic phenomena that occur along with the findings of various previous studies, it is important to analyze the Corporate Governance Index, Corporate Ownership Structure and Audit Committee on Debt Costs.

\section{Literature Review and Hypothesis Development}

\subsection{Agency Theory}

According to Jensen and Meckling (1976) defining agency relationships as a contract under one or more principals involving agents to carry out several services by delegating authority in decision making to agents. The main purpose of agency theory is to explain how parties to a contractual relationship can design a contract whose purpose is to minimize costs as a result of asymmetric information and uncertainty conditions. Agency theory is related to Good Corporate Governance because it explains matters related to the relationship between shareholders (principal) and management (agent). As an agent, the manager is morally responsible for optimizing the profits of the owners (Principal). In implementing corporate governance, it is expected to provide trust in management as an agent in managing the 
principal's wealth as the owner of capital. Corporate Governance is used as a tool to ensure that directors and managers will act in the best interests of stakeholders in general and shareholders in particular (Meiriasari, 2017).

\subsection{Corporate governance}

Corporate governance is a regulation regarding the relationship between shareholders, company managers, creditors, government, employees, and other internal and external holders relating to their rights and obligations. Corporate Governance is applied to improve the performance and accountability of the company in optimizing the value of shareholders in the long run while still taking into account the interests of other stakeholders and based on ethical values and applicable laws and regulations. Implementation of good corporate governance is expected to increase public confidence, especially investors and creditors, towards the company (Meiriasari, 2017).

For a corporate governance company it is important to increase and maximize the value of the company, improve company management in a professional, efficient and transparent manner. Based on agency theory, good corporate governance practices can increase the value of the company by increasing financial performance, reducing risk and can increase investor confidence, so that the company can be more targeted to achieve its goals.

Several previous studies conducted by Ashkhabi and Agustina (2015), Sari et al (2018) and Hamid et al (2019) stated that the corporate governance index had a negative effect on the cost of debt. Based on the description, the first hypothesis to be tested in this study is as follows:

H1: Corporate governance index has a negative effect on the cost of debt.

\subsection{Managerial ownership}

Managerial ownership is a situation where a manager in a company is also a shareholder in the company. In certain companies to motivate manager performance, start implementing managerial ownership policies. This policy is to provide opportunities for managers involved in share ownership so that the involvement of these managers can reduce the information asymmetry in a company.

This is in line with agency theory. It is expected that the involvement of managers in share ownership can effectively improve manager performance (Ashkhabi, 2015). The implementation of agency theory in managerial ownership can make managers more careful in making decisions related to debt policy. Managers can reduce the amount of debt to minimize the risk that will occur and affect the decision of creditors.

In research conducted by Saputra and Faizal (2016), Septian and Panggabean (2016), Octafilia and Sandika (2018) and Wardani and Rumahorto (2018) stated that managerial ownership has a positive effect on debt costs. Related to the explanation, the second hypothesis to be tested in this study is as follows:

H2: Managerial ownership has a positive effect on the cost of debt.

\subsection{Institutional ownership}

Institutional ownership is a corporate governance mechanism that can be used to control agency problems through increased optimal oversight of management performance (Meiriasari, 2017). This is in line with agency theory since institutional ownership can help management to monitor company performance so that the risk owned by the company will be smaller and creditors can provide a lower return on the amount of funds lent to the company (Yunita, 2012). In research conducted by Agustami and Yunanda (2014), Ashkhabi 
and Agustina (2015), Rahmawati (2015), Mahmoudi and Hashempour (2016), Meiriasari (2017) and Octafilia and Sandika (2018) state that institutional ownership negatively affects the costs debt. Based on these explanations, the third hypothesis that will be tested in this study is as follows:

H3: Institutional ownership has a negative effect on the cost of debt.

\subsection{Audit committee}

Audit committee is a committee formed by the board of commissioners in order to help carry out its duties and functions, namely overseeing the performance of company management. This is in line with agency theory since an effective audit committee will produce an internal company with effective performance that leads to an increase in the company's reputation that will increase creditor confidence and affect the low cost of debt (Raharja and Prasetyo, 2013). According to agency theory it can reduces conflict between principal and agents.

In a study conducted by Kurniawati (2014), Rahmawati (2015), Pranaditya, et al (2018) and Sari, et al (2018) stated that the audit committee had a negative effect on debt costs. Based on the description, the fourth hypothesis that will be tested in this study is as follows:

H4: The Audit Committee has a negative effect on the cost of debt.

Based on the description, the framework of this research is as follows:

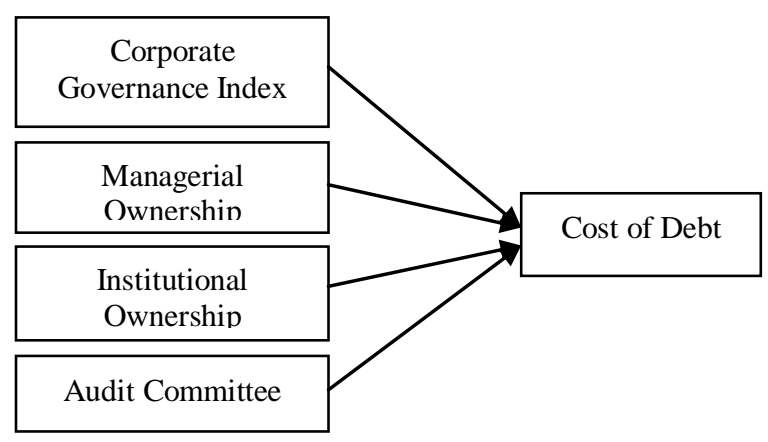

\section{Research Method}

This research is a quantitative study using secondary data derived from the financial statements of companies participating in the Corporate Governance Perception Index (CGPI) for 2014-2018 which are listed on the Indonesia Stock Exchange. The population of this study was all CGPI participating companies in Indonesia which were listed on the Indonesia Stock Exchange during 2014-2018 which were taken using the purposive sampling method as a sampling technique. This study uses multiple regression analysis to test the hypothesis.

\subsection{The Variables Measurement}

The cost of debt (COD) is calculated from the large interest expense paid by the company in a one-year period divided by the average number of loans that generate interest. The formula used to calculate COD (Ashkhabi, 2015) is:

$$
\mathrm{COD}=\frac{\text { Interest Expense }}{\text { Average Long Term Debt }} \times 100 \%
$$

Corporate Governance Index (CGI). An assessment of the application of GCG by the Indonesian Institute for Corporate Governance requires companies to continue to develop and improve the quality of corporate governance from various perspectives on an ongoing basis. CGI is measured using the weight of research assessment and CGPI ranking each year (Sari et al, 2018).

Managerial ownership in this study will be measured based on the percentage of managerial ownership or can be calculated by the following formula (Ashkhabi, 2015):

MAN $=\frac{\text { Management Share Ownership }}{\text { Total Outstanding Share }} \times 100 \%$

Figure 1. Research Framework 
Institutional Ownership is measured using a percentage of the proportion of institutional ownership in the company's shareholding structure using the following formula (Ashkhabi, 2015):

$$
\text { INST }=\frac{\text { Institutional Share Ownership }}{\text { Total Outstanding Share }} \times 100 \%
$$

The audit committee in this study was measured using the number of audit committee members in the company.

\section{Results and Discussion}

The results of multiple linear regression analysis in this study are as follows:

Table 1. Result of Multiple Regression

\begin{tabular}{|c|c|c|}
\hline \multicolumn{2}{|r|}{ Model } & $\begin{array}{c}\text { Unstandardized } \\
\text { Coefficients }\end{array}$ \\
\hline \multirow[t]{5}{*}{1} & (Constant) & 3,348 \\
\hline & Corporate Governance Index & $-0,024$ \\
\hline & Managerial Ownership & $-0,200$ \\
\hline & Institutional Ownership & $-0,010$ \\
\hline & Audit Committee & $-0,051$ \\
\hline
\end{tabular}

Source: Data Processed (2019)

Based on the results of the SPSS output in table 1, the regression equation can be arranged as follows:

COD $=3,348-0,024$ CGI $-0,200$ MAN $-0,010$ INS $-0,051$ KOM_AUD $+\varepsilon$

Table 2. Adjusted $\mathrm{R}^{2}$ Result

\begin{tabular}{|l|c|r|r|c|}
\hline Model & $R$ & $R$ Square & $\begin{array}{c}\text { Adjusted } R \\
\text { Square }\end{array}$ & $\begin{array}{c}\text { Std. Error of the } \\
\text { Estimate }\end{array}$ \\
\hline 1 & $0,618^{\mathrm{a}}$ & 0,382 & 0,252 & 0,156650 \\
\hline
\end{tabular}

a. Predictors: (Constant), Komite Audit, Kepemilikan Manajerial, Kepemilikan Institusional, Corporate Governance Index

Based on table 2 Adjusted R Square test results in this study obtained the value of $R$ Square of 0.252 . This means that the influence of CGI, managerial ownership, institutional ownership and audit committee influences $25.2 \%$ of the cost of debt. While the remaining $74.8 \%$ is influenced by other variables not examined in this study.

Table 3: The Result of Hypothesis Testing

\begin{tabular}{|l|l|c|c|}
\hline \multicolumn{1}{|c|}{ Model } & $\begin{array}{c}\text { Unstandardized } \\
\text { Coefficients } \\
\text { B }\end{array}$ & $\mathrm{T}$ & Sig \\
\hline 1 (Constant) & 3,348 & 3,145 & 0,005 \\
\hline Corporate Governance Index & $-0,024$ & $-2,170$ & 0,043 \\
\hline Manageria Ownershipl & -0.200 & $-1,528$ & 0,143 \\
\hline Institutional Ownership & $-0,010$ & $-2,315$ & 0,032 \\
\hline Audit Committee & $-0,051$ & $-1,483$ & 0,154 \\
\hline
\end{tabular}

a. Dependent Variabel Biaya Hutang

\subsection{The corporate governance index has a} negative effect on the cost of debt

Based on the output of table 3, the CGI obtained a significant value of 0.043 less than 0.05 and the $-t_{\text {count }}-2,170<-t_{\text {table }}$ 1,68595 indicates that the corporate governance index variable influences the cost of debt. The regression coefficient value indicates the direction of -0.024 . Thus the first hypothesis (H1) which states that the corporate governance index has a negative effect on the cost of debt is declared acceptable.

An increasing in the percentage of CGI owned by the company will cause a decrease in debt costs. Conversely, a decrease in the percentage of CGI owned by the company will increase debt costs. These results are in accordance with agency theory which explains that there is an agency relationship between managers and principals, the proportion of share ownership by company management can affect the level of corporate debt costs. a manager will prioritize and prioritize his own interests, namely to get personal benefits that can harm shareholders as principals.

The results of this study are consistent with research conducted by Askhabi and Agustina (2015), Sari et al (2018), Erniawati and Mawardi (2019) which prove that the corporate governance index has a negative effect on debt costs. 
4.2 Managerial ownership does not affect the cost of debt

Managerial ownership obtains a significant value of 0.143 over 0.05 and a value of $\mathrm{t}_{\text {count }}-1,528<\mathrm{t}_{\text {table }} 1,68595$, indicating that the variable of managerial ownership has no effect on the cost of debt. Thus the second hypothesis (H2) which states that managerial ownership has a positive effect on the cost of debt is rejected.

Changes due to increase or decrease in the company's managerial ownership shares will not affect the cost of debt. The results of this study are not in line with agency theory which states that managerial ownership in the company will unite the interests of agents and shareholders so that managers will act as expected. The managerial ownership samples studied yielded a relatively small average that did not affect the cost of debt. Although the sample of managerial shares yields $72 \%$, the average managerial ownership tends to be small.

The findings in this study are consistent with research conducted by Nugroho and Meiranto (2014), Samhudi (2016) and Erniawati and Mawardi (2019) proving that managerial ownership has no effect on debt costs. however, this study is not in accordance with research conducted by Octafilia and Sandika (2018) and Wardani and Rumahorto (2018) which prove that managerial ownership has a negative effect on the cost of debt.

\subsection{Institutional ownership negatively affects the cost of debt}

Institutional ownership obtained a significant value of 0.032 less than 0.05 and the value of $-t_{\text {count }}-1,884<-t_{\text {table }} 1,68595$ indicates that the variable of institutional ownership affects the cost of debt. The regression coefficient value indicates the direction of -0.010 . Thus the third hypothesis (H3) which states that institutional ownership negatively affects the cost of debt is accepted.

An increasing in institutional ownership in the company will have an impact on reducing the cost of debt. Conversely, a decrease in institutional ownership in the company will have an impact on increasing the cost of debt. These results are in accordance with agency theory which states that institutional ownership influences monitoring actions carried out by management. The greater the level of share ownership by an institution, the more effective the mechanism of control over management performance and prevents fraud by managers.

The findings in this study are consistent with studies conducted by Ashkhabi and Agustina (2015), Meiriasari (2017), Octafilia and Sandika (2018), and Erniawati and Mawardi (2019) which prove that institutional ownership negatively influences the cost of debt.

\subsection{The audit committee has no effect on the cost of debt}

The audit committee obtained a significant value of 0.154 over 0.05 and the magnitude of $-t_{\text {count }}-1,483<-t_{\text {table }}$ 1,68595 indicates that the audit committee variable had no effect on the cost of debt. Thus the fourth hypothesis (H4) which states that the audit committee negatively affects the cost of debt is declared rejected.

An increase or decrease in the audit committee does not affect the cost of debt. The audit committee in the company has not been able to ensure that the financial statements are fairly presented based on generally accepted accounting principles, so that the audit committee has not been able to contribute to reducing debt costs. The results of this study are not in line with agency theory which states that an effective audit committee will produce companies that perform effectively which lead to an 
increase in the company's reputation that will increase creditor confidence.

The results of this study are consistent with research conducted by Prasetyo and Raharja (2013), Wardani and Rumahorbo (2018), and Zahro and Mawardi (2018) which state that the audit committee has no effect on debt costs. However, this study is not in accordance with research conducted by Kurniawati (2014) and Rahmawati (2015) which states that the audit committee has a negative effect on the cost of debt.

\section{Conclusion}

Based on the results of data analysis and discussions that have been carried out, it can be concluded that the Corporate Governance Index and institutional ownership negatively affect the cost of debt. Whereas managerial ownership and audit committee do not affect on the cost of debt.

The implications of the findings in this study can be beneficial for investors in assessing the governance of a company in managing its debt. investors can consider for an investment decision both long term and short term.

The limitation in this study is the low value of Adjusted R Square of $25.2 \%$ so that in this study there are several independent variables that do not affect the cost of debt. in addition, this study only uses CGI data from companies that have a very trusted category, so the sample they have is very limited.

Suggestions for further research is to increase the scope of CGI categories, so that the sample is more clustered and is expected to have a significant effect on the dependent variable.

\section{References}

Adam, M., Mukhtaruddin, M., Soraya, N., \& Yusrianti, H. (2015). Good Corporate Governance and Cost of Debt Listed Companies on Indonesian Institute for
Corporate Governance. Asian Social Science, Vol 11 No.25, hal 58-77.

Agustami, S., \& Yunanda, A. C. (2014). Pengaruh Kepemilikan Institusional dan Pengungkapan Sukarela terhadap Biaya Hutang. Jurnal Riset Akuntansi dan Keuangan, 2(2), 376-391.

Ashkhabi, I. R., \& Agustina, L. (2015). Pengaruh Corporate Governance, Struktur Kepemilikan Perusahaan dan Ukuran Perusahaan Terhadap Biaya Utang. Accounting Analysis Journal, 4(3).

Erniawati, I., Hidayati, N., \& Mawardi, M. C. (2019). Pengaruh Corporate Governance Index, Kepemilikan Institusional dan Kepemilikan Manajerial terhadap Biaya Utang. Jurnal Ilmiah Riset Akuntansi, $8(07)$.

Ghozali, I. (2013). Aplikasi Analisis Multivariate dengan Program IBM SPSS, Edisi ketujuh. Badan Penerbit Universitas Diponegoro. Semarang.

Hamid, A. A., Irwansyah, I., \& Kusumawardani, A. (2019). Pengaruh corporate governance index, kepemilikan keluarga, kepemilikan institusional terhadap biaya ekuitas dan biaya hutang pada perusahaan manufaktur go publik di indonesia. Jurnal Ilmu Akuntansi Mulawarman (JIAM), Vol 3 No. 1.

Izanin. (2019). Pengaruh Corporate Governance Index, Struktur Kepemilikan Perusahaan dan Ukuran Perusahaan Terhadap Biaya Hutang. Skripsi Jurusan Akuntansi. Universitas Muhammadiyah Purwokerto.

Jensen, M.C. \& W. Meckling. (1976). Theory of the Firm: Managerial Behavior, Agency Costs, and Capital Structure. Journal of Financial Economics, 3:305-360.

Juniarti \& Sentosa, (2009). Pengaruh Good Corporate Governane, voluntary Disclosure Terhadap Biaya Hutang (Cost of Debt). Jurnal akuntansi dan keuangan, Vol. 11 No. 2, 88-100.

Kurniawati, Z (2014). Pengaruh Penerapan Good Corporate Governance Terhadap Biaya utang pada perusahaan manufaktur di Indonesia. Jurnal Bisnis dan Ekonomi, Vol 5 No.2, hal 195-206. 
Mahmoudi, Z., \& Hashempour, A. (2016). Examining the Effect on Ownership Structure of the Relationship between bsm and Debt Cost of companies Accepted $\neg$ in Tehran Stock Exchange. International Journal of Humanities and Cultural Study.

Meiriasari, V. (2017). Pengaruh Corporate Governance, Kepemilikan Keluarga, Kepemilikan Institusional dan ukuran perusahaan (Firm Size) Terhadap Biaya Utang. Jurnal Ekonomi Global Masa Kini, Vol 8 No.1, hal 28-34.

Nazmi H.T. (2018). Daya Tahan Enam Perusahaan Grup Lippo menanggung hutang. 29 mei, 2018 Web site:https://katadata.co.id/analisisdata/2018/ 05/29/daya-tahan-enam-perusahaan-gruplippo-menanggung-utang.

Nugroho, D. R., \& Meiranto, W. (2014). Pengaruh Good Corporate Governance Terhadap Biaya Ekuitas dan Biaya Hutang (Studi pada Perusahaan Manufaktur yang Terdaftar di BEI pada Tahun 2010-2012). Diponegoro Journal of Accounting, Vol 3 No. 3, hal 316-3.

Octafilia, Y., \& Sandika, J. A. (2018). Pengaruh Kepemilikan Institusional, Kepemilikan Manajerial dan Kualitas pada Perusahaan Pertambangan Yang Terdaftar Di BEI Tahun 2014-2016. Bilancia Jurnal Ilmiah Akuntansi, Vol 2 No. 1, hal 95-106.

Prasetyo, R. E., \& Raharja, S. (2013) Analisis Pengaruh Kualitas Auditor dan Komite Audit terhadap Cost Of Debt dengan Usia Perusahaan sebagai Variabel Pemoderasi (Studi pada Perusahaan yang melakukan IPO di Bei Tahun 2008-2012). Diponegoro Journal of Accounting, Vol 2 No.3, hal 112.

Rahmawati, R. (2015). Pengaruh Penghindaran Pajak Dan Good Corporate Governance Terhadap Biaya Utang (Studi Empiris Perusahaan Manufaktur yang Terdaftar di BEI Tahun 2009-2013). Jurnal Akuntansi, Vol 3 No.1, hal 3-33.

Rebecca, Y. (2012). Pengaruh Corporate Governance Index, Kepemilikan Keluarga, dan Kepemilikan Institusional terhadap Biaya Ekuitas dan Biaya Utang Studi Empiris Pada Perusahaan Manufaktur yang terdaftar di BEI. Simposium Nasional Akuntansi $X V, 1-28$.

Samhudi, A. (2016). Pengaruh Good Corporate Governance dan Voluntary Disclosure Terhadap Biaya Hutang (Cost Of Debt). Jurnal Akuntansi, Vol. 3 No. 2. JuliDesember 2016.

Saputra, M. \& Faizal, M. (2016). The Influence of Corporate Governance Index, Managerial Ownership, Government Ownership and Sales Growth on Cost of Debt (Study in Non-Financial Companies Listed on IDX Year 2011-2014). Journal of Research in Business, Economics and Management, Vol. 6, Issue 2, June 8, 2016. 